(4) へロドイコスとプラトーン

(5) 結 語

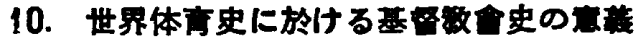

(Significance of Church history in history of world phipical education.

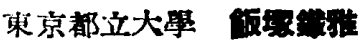

ヘレニズムそーブライズムとの交錯に落眼點を 占き，古代文化に於ける体育が祭典的意味に於て なされた如く聖なる價值を具現せる其の間の史的 䤑古と同時に，何故に体育が本來目然のまろの一 次元的形奖に於ては一般に轉換さるべきしのでら るにもからわらす人間最高至上の傊傎具現の重要

\title{
12. 是校保健の史的放案
}

福島大學 鈴木源大

1) 考察の目的

（1）校健は從來の學校衛维に比して高く呠 㵋されるやうになつたがそれは直接的には新教育 思潮の示唆にょるものを思われる。しかしそれは 終戰後白紙の上に煡生したものではない子思ふの で,この際我が國學校保健の史的考察によつて今 後の新學校保垏の理念動向を確認したい。

（2）保健と体育との關係は種々の角度から問題 にされて居るから，我が國學校保健の史的考察に よつて，保健及体青の概念規定等にるこのいとく ちを見つけたい。

2) 考察の內容

（1）明治以前の保健思想及事害

（2）明治以後今日まで行政上，数育上, 制度上

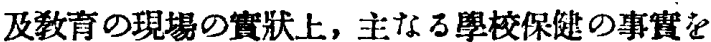
年次順に拢き出してそれについて考察する。

3) 結 果

（1）新學校保健の理念動司在知る

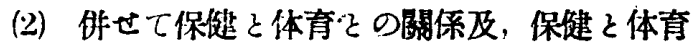
の概念について示唆を得る。

13. 大临に於ける 数盖としての体㨽の理想

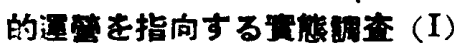

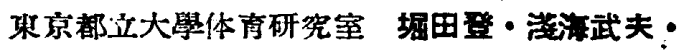

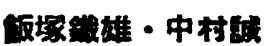

なる素因たり得たのか，或いは又へレンズムが挠 りなす糜史的時間の流々に在つて体育は如何に糿 餘曲折して來たか，そして现代スポーツがキリス ト数々理或いはェドンゼリズムに如何に結合して 今日に到つたか，果してキリスト数的世界覒が中 世から今日に到る歷史に於て鹖育の淮展に些かで もマイナスの契譏を提示しているか等々考察し体 育倫理學的間題より体育僧値論に及びたい.

\section{1. キリスト数と体拄}

请山登院大學体有科研究空 東次右工閒・相 馬武饶・田所瞵太

年後之部（牛後 1 時〜洔）

本校に於いては体育原簿を作り，學学の效果， 心身の特性，環境等の諸面に關した，休育渾動の

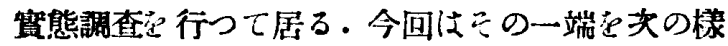
な樣式に体り發表したいと思ふ。

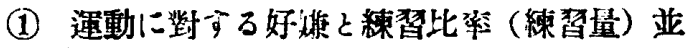
びに技琎の程度（尺度を與へ白已評價に依る）

(2) 形態と機能（体格飞渾動能力）

(3) 性格の自己許價（尺度はこちらで與ふ） 之等の覞點を次の三つの分野から探究して見る。 尙この三つの分野は，我くの研究公並びに本校の 特色と考人られる點なり。

(1) 研究室の特色

体青椠拔の護座を野球並びにソフト，バレー， バスケット，柔道の四種目として居るがこれらの 種目による相幥。

(2) 本校の特色

(1) 理學部, 人文學部, 工學部の三つの學部 についての相連

(听意間部と夜間部の別による相迬 大体に於いて今回の磁表には上上のみに止りる

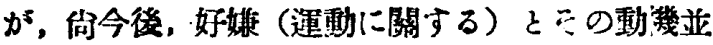
びにその批制, 体格，運動能力子學業成嘖との相 闒，學習の効果，環境の及ぼす影響等回军重れて

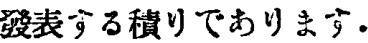

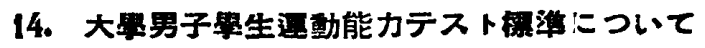
（第 1 赫）

金渪大學体育研究室 